\title{
Effect of Profitability, Liquidity, and Dividends Per Share on Share Prices of Construction Companies Listed on The Indonesia Stock Exchange For the Period 2015-2019
}

\author{
Zhammuel Nobel Harjuna \\ Faculty of Economics and Business, Narotama University, Surabaya, Indonesia
}

\begin{abstract}
The purpose of this research is to find out if return of assets, current ratio and dividends per share affects the Share Price. This research uses a Quantitative approach. Sampling is done with purposive sampling techniques and selected as many as 9 companies that can be researched. The data in this study comes from secondary data obtained through IDX. The results of this study can be concluded that there is a significant influence between Return Of Assets, Current Ratio and Dividends Per Share on the Share Price. In addition, hypothesis testing in this study used Multiple Linear Regression with the help of SPSS Version 20 applications.
\end{abstract}

Keywords: Return of Assets, Current Ratio, Dividen Per Share, Affects the Share Price.

\section{Introduction}

The development and construction sector is one of the strongest sectors supporting economic growth in Indonesia. A study conducted by the Central Bureau of Statistics (BPS) showed that the construction sector came in third as the main source of Indonesia's economic growth. The growing construction sector made Indonesia's economy in 2017 grow by $5.01 \%$ and GDP by $10.38 \%$, higher than the previous year which only contributed $0.51 \%$ in 2016 and in 2015 which only reached $4.88 \%$ (Alexander, 2017).

The contribution of construction in the Indonesian economy is considerable, 10.76 percent to Indonesia's Gross Domestic Product (GDP) in the first quarter of 2019. The Central Bureau of Statistics (BPS) monitors construction development through the Quarterly Construction Survey conducted on stale construction companies (M1, M2, B1, and B2 qualifications) in Indonesia. The value of construction sector work depends on the physical realization of the work of projects completed in a period of one quarter. The construction value index for the first quarter of 2018 was 286.58 and 314.04 in 2019. Fluctuations in the construction value index completed by the construction sector. During the period 2018 quarter I, in general the conditions and business prospects of the majority of entrepreneurs on the progress of the construction sector are more optimistic. This is reflected in the magnitude of its index value which is greater than $(>50)$, which is indicated by the business condition index value of 52.10 and the business outlook of 57.01 in the first quarter of 2018. Meanwhile, in the first quarter of 2019 the majority of entrepreneurs are pessimistic about the current business conditions, but they are optimistic that in the second quarter of 2019 will have a better prospect. This is seen from the estimated business conditions index of $46.90(<50)$ and the business outlook index of $57.38(>50)$ in the first quarter of 2019.

From the 9 construction companies contained on the Indonesia Stock Exchange (IDX) researchers took example 1 in the company Ascet Indonusa Tbk. That net profit in 2018 was 3,725,296 and in 2019 had a net profit value of $3,947,173$ here researchers can draw the conclusion that in 2018 to 2019 (www.idx.co.id) experienced a considerable increase on the previous year.

\footnotetext{
* Corresponding author.

E-mail address: zhammuel.gabil1998@gmail.com (Zhammuel Nobel Harjuna)
} 
Researchers hope to process empirical evidence of the share price through its financial system represented by the Profitability Ratio for Return Of Assets (ROA) while liquidity ratio by focusing current ratio and Dividend Per Share on The Price of shares in Construction companies listed on the Indonesia Stock Exchange (IDX) Period 2015 - 2019. This study used secondary data found on the Indonesia Stock Exchange with a population of 18 Construction Companies. And the research method uses Purposive Sampling technique.

The financial aspect of Icon is an important icon in building trust in stakeholders and investors towards performance in the construction company and influences not some variables such as Return of Asset, Current Ratio and Dividend Per Share expected share price by conducting research through various web and journals. The share price is one of the important indicators in a company, it shows how much interest investors have to invest in a company. And the share price is also an indicator of management's success in managing the company. If a company's share price always increases or profits increase every year then, investors or prospective investors argue that the management of the company has been successful in managing its business. This will certainly give rise to more confidence for investors or potential investors to invest in the company. In principle if the company can make a profit every year then, this can certainly increase the demand for shares owned by the company. If this is the case then indirectly the company's share price will increase higher than before due to investor confidence or potential investors in the company. Similarly, if the company does not show an increase in profit year on year then, this will affect the demand for the company's own shares. If this happens indirectly it will affect the share price of the company.

The high share price of a company can be influenced by many factors in the company's financial performance, investor demand and supply, interest rates, risk levels, pace of infaction government policy and politics. Nevertheless, financial performance conditions in general still have a dominant influence on the formation of stock prices. generally, financial performance analysis techniques are used to vaccinate past performance by conducting various so that they are obtained positions that represent the company's reality and potential financial performance that will continue.

Kasmir (2014), profitability ratio is "ratio to assess the company's ability to make a profit". A consistent level of profitability will be the benchmark for how the company is able to survive in its business by earning adequate returns when compared to the risks. So the higher the profit earned then the more likely the company will experience financial distress the smaller. Cashmere (2014) explains that "liquidity ratio is a ratio that indicates or measures the company's ability to meet its maturing obligations, both obligations to outside the company and within the company. Dividends Per Share are an important component that should be considered in the company's analysis. Because dividend per share information can show the amount of share dividend owned by investors and can also show the entire dividend payment in numbers per share.

\section{Literature Review}

\subsection{Share Price}

According to Hartono (2013), the share price is the price that occurs in the exchange market at any given moment and the share price is determined by the market participants. The high low share price is determined by the demand and offering of the shares in question in the capital market. The share price is a reflection of investor expectations of the earnings, cash flow, and return factors required by 11 investors, all three of which are also heavily influenced by a country's macroeconomic conditions as well as global economic conditions (Schwaiger, et.al., 2020; Tandelilin, 2020).

The understanding of the Stock itself is a valuable document that shows the share of the investor's ownership of a company. In other words, when a person buys shares then the person has proof that the investor has purchased a portion of ownership of the company. And the meaning of the stock itself can also be interpreted as a unit of value or bookkeeping in various Financial instruments that can refer to the ownership part of a company. in other words, if the investor has purchased shares in the company in other words, the person mentioned has owned ha katas asset and the company's income with a portion of the shares purchased and obtained the dividend per share. 


\subsection{Profitability}

Profitability Ratio is a ratio or comparison to determine the company's ability to profit from earnings related to sales, assets and equity based on a specific measurement basis. These types of profitability ratios are used to show how much profit or profit is derived from a company's performance affecting notes on financial statements that must comply with financial accounting standards.

Profitability ratio is ratio to assess the company's ability to make a profit (Kasmir, 2014; Willy, 2017). A consistent level of profitability will be the benchmark for how the company is able to survive in its business by earning adequate returns when compared to the risks. So the higher the profit earned then the more likely the company will experience financial distress the smaller. Types of profitability ratios, among others:

\section{a. Return Of Assets (ROA)}

Return On Assets (ROA) is a ratio that shows the result of the amount of assets used in the company (Rusnindita, 2020; Kasmir, 2014).

Return On Assets is one of the profitability ratios that can measure the company's ability to generate profit from the assets used, according to Kasmir (2014), Return On Assets is a ratio that shows the yield on the amount of assets used in the company.

$$
\text { Return of Assets }=\frac{\text { Earning after Interest and Tax }}{\text { Total Activa }} \times 100
$$

The larger this ratio is considered the better the ability of the company to make a high profit, and vice versa.

\section{b. Return On Investment (ROI)}

Return On Investment is the return on investment or better known as Return on Investment (Kasmir, 2014). ROI is a ratio that shows the return on the amount of assets used in the company. ROI is also a measure of the effectiveness of management in managing its investments. The formula for finding Return on Investment can be used as follows (Kasmir, 2014):

$$
\text { Return on Investment }=\frac{\text { Earning after Interest and Tax }}{\text { Total Assets }}
$$

The smaller (low) this ratio the less good it is, and vice versa. This means that this ratio is used to measure the effectiveness of the company's overall operations.

\section{c. Return On Equity (ROE)}

The return on equity or capital gains alone is the ratio to measuring net profit after tax with its own capital (Fauzi \& Rukmini, 2018; Kasmir, 2014). The formula for finding return on equity can be used as follows (Kasmir, 2014):

$$
\text { Return on Equity }=\frac{\text { Earning after Interest and Tax }}{\text { Equity }}
$$

This ratio indicates the efficiency of capital use itself. The higher this ratio, the better. That means the position of the owner of the company is stronger, and vice versa. 


\subsection{Liquidity}

Liquidity ratio is a ratio that demonstrates a company's ability to meet its obligations or pay its short-term debt. This ratio can be used to measure how liquid a company is. If the company is able to fulfill its obligations it means the company is liquid, whereas if the company is unable to fulfill its obligations it means the company is liquid.

Liquidity Ratio explains that "liquidity ratio is a ratio that indicates or measures the company's ability to meet its maturing obligations, both obligations to outside the company and within the company (Kasmir, 2014). Liquidity ratio is a ratio that indicates the relationship between corporate cash and other current assets with current debt (Brigham, 2010).

\subsection{Dividends Per Share}

The definition of dividend per share (DPS) According to Reeve et al (2010: 275) stipulates as follows that cash flow is paid to shareholders.

Dividends Per Share are an important component that should be considered in the company's analysis. Because dividend per share information can indicate the amount of share dividend owned by investors and can also show all dividend payments in numbers per share and According to Syamsuddin (2009) dividend per share is a payment distributed by the board of directors of the company among the shareholders.

According to Syamsudin (2009:30) dividends are payments made to company owners or shareholders for the capital they invest in the company. and dividend distribution is generally based on accumulated profit, i.e. retained earnings, or on some other capital post such as additional paid-up capital.

The following components are included in the Dividend Per Share calculation:

Dividends Per Share (DPS) are the total of all cash dividends distributed to shareholders compared to the outstanding amount. Dividend Per Share (DPS) is the amount of dividend distribution that will be distributed to shareholders after being compared to the weighted average of common shares outstanding (Ahmed, Advani, \& Kanwal, 2018; Weston \& Copeland, 1997).

\subsection{Relationships Between Variables}

\subsubsection{Relationship of Profitability to Share Price}

Profitability Ratio is a ratio or comparison to determine the company's ability to profit from earnings related to sales, assets and equity based on a specific measurement basis. These types of profitability ratios are used to show how much profit or profit a company earns that affects the record of financial statements that must comply with financial accounting standards.

Self-Profitability Ratio By Kasmir (2014), profitability ratio is "ratio to assess the company's ability to make a profit".

\subsubsection{Liquidity Relationship to Share Price}

Liquidity ratio is a ratio that demonstrates a company's ability to meet its obligations or pay its short-term debt. This ratio can be used to measure how liquid a company is. If the company is able to fulfill its obligations it means the company is liquid, whereas if the company is unable to fulfill its obligations it means the company is liquid.

Liquidity Ratio by Kasmir (2016) explains that "liquidity ratio is a ratio that indicates or measures the company's ability to meet its maturing obligations, both obligations to outside the company and within the company. Liquidity ratio is a ratio that indicates the relationship between corporate cash and other current assets with current debt (Brigham, 2015). 


\subsubsection{Dividend Per Share Relationship to Share Price}

Dividends Per Share are an important component that should be considered in the company's analysis. Because dividend per share information can indicate the amount of share dividend owned by investors and can also show all dividend payments in numbers per share and According to Syamsuddin (2009) dividend per share is a payment distributed by the board of directors of the company among the shareholders.

According to Syamsudin (2009) dividends are payments made to company owners or shareholders for the capital they invest in the company. and dividend distribution is generally based on accumulated profit, i.e. retained earnings, or on some other capital post such as additional paid-up capital.

\section{Methods}

\subsection{Research Approach}

Research is essentially to show the truth and problem solving of what is researched to achieve that goal, performed an appropriate and relevant method for the purpose examined.

The research approach the authors used in this study is a quantitative approach. Descriptive-Verifiative research method that is intended to explain the phenomena that occur in the object of research widely about the problems studied using the tools and statistical data of econometrics as proof of hypothesis of the problem so that it can be drawn a theoretical conclusion that can answer the problem. The phenomenon that you want to explain here is that volatile stock prices are influenced by profitability, leverage, and Liquidity. The research location is on the Jakarta Stock Exchange (IDX) by downloading the official data of the Indonesia Stock Exchange (IDX) in www.idx.co.id and the Indonesian Capital Market Directory (ICMD). The analysis unit in this study is an organization in the construction companies on the Indonesia Stock Exchange in 2015-2018.

Population The population used in this study is a company engaged in Construction on the Indonesia Stock Exchange which numbered 18 companies. The period 2015-2019 (5 years) is used as an observation period because with that time span it is expected that there will be a sufficient number of research samples and can be generalized.

Table 1. Construction Company Population

\begin{tabular}{llll}
\hline No & Code & Company & Date \\
\hline 1. & ACST & Ascet Indonusa Tbk & 24 June 2013 \\
2. & ADHI & Adhi Karya (Persero) Tbk & 18 March 2004 \\
3. & CSIS & Cahayasakti Investindo Sukses Tbk & 10 May 2017 \\
4. & DGIK & Nusa Konstruksi Enjiniring Tbk & 19 December 2007 \\
5. & IDPR & Indonesia Pondasi Raya Tbk & 10 December 2015 \\
6. & MTRA & Mitra Pemuda Tbk & 10 February 2016 \\
7. & NRCA & Nusa Raya Cipta Tbk & 27 June 2013 \\
8. & PBSA & Paramita Bangun Saran Tbk & 28 September 2016 \\
9. & PSSI & Pelita Samudera Shipping Tbk & 05 December 2017 \\
10. & PTPP & Pembangunan Perumahan (Persero) & 09 February 2010 \\
11. & SKRN & Superkrane Mitra Utama Tbk & 11 October 2018 \\
12. & SSIA & Surya Semesta Internusa Tbk & 27 March 1997 \\
13. & TAMA & Lancartama Sejati Tbk & 10 February 2020 \\
14. & TOPS & Totalindo Eka Persada Tbk & 16 June 2017 \\
15. & TOTL & Total Bangun Perseda Tbk & 25 July 2006 \\
16. & WEGE & Wijaya Karya Bangunan Gedung Tbk & 30 November 2017 \\
17. & WIKA & Wijaya Karya (Persero) Tbk & 29 October 2007 \\
18. & WSKT & Waskita Karya (Persero) Tbk & 19 December 2012 \\
\hline
\end{tabular}




\subsection{Sample}

Arikunto (2010), a data collection instrument is a tool chosen and used by researchers in its activities to collect data so that the activity becomes systematic and made easier by it. Data collection on research using Purposive sampling techniques. Purposive sampling is one of the non random sampling techniques where researchers determine sampling by setting special characteristics that fit the purpose of the study so that it is expected to answer the research problems.

The samples in this study were conducted through purposive sampling methods and obtained samples of 9 companies whose shares were actively traded during the observation period.

Table 2. Sample

\begin{tabular}{llll}
\hline No & Code & Company Construction & Date \\
\hline 1. & ACST & Ascet Indonusa Tbk & 24 June 2013 \\
2. & ADHI & Adhi Karya (Persero) Tbk & 18 March 2004 \\
3. & DGIK & Nusa Konstruksi Enjiniring Tbk & 19 December 2007 \\
4. & NRCA & Nusa Raya Cipta Tbk & 27 June 2013 \\
5. & PTPP & Pembangunan Perumahan (Persero) & 09 February 2010 \\
6. & SSIA & Surya Semesta Internusa Tbk & 27 March 1997 \\
7. & TOTL & Total Bangun Perseda Tbk & 25 July 2006 \\
8. & WIKA & Wijaya Karya (Persero) Tbk & 29 October 2007 \\
9. & WSKT & Waskita Karya (Persero) Tbk & 19 December 2012 \\
\hline
\end{tabular}

\subsection{Objects}

The research object used in this study is a company engaged in Construction on the Indonesia Stock Exchange in 2015 - 2018 which numbered 18 companies and after further research there are 9 samples of companies that can be filtered further. The period 2015 - 2019 (5 years) is used as an observation period because with that time span it is expected that there will be a sufficient number of research samples and can be generalized.

\subsection{Types, Sources and Techniques of Data Collection}

This research used secondary data sources obtained through the internet, and the secondary data itself is research data that was previously obtained indirectly through intermediaries, obtained from the Indonesia Stock Exchange (IDX) and with some blessing literature. This data collection technique itself uses quantitative data collection techniques that obtain data through the internet where the data collected becomes the basis for the creation of this thesis.

\subsubsection{Data Types}

The type of data that researchers uses data that has data Time Series characteristics. The meaning of the Data Time Series concept itself is data that has a time run of more than a year on an object with a considerable period of time. This type of data is taken by the researcher using secondary data retrieval through the Indonesia Stock Exchange internet.

\subsubsection{Data Sources}

This research used secondary data sources obtained through the internet, and the secondary data itself is research data previously obtained indirectly through intermediaries, obtained from the Indonesia Stock Exchange (IDX) and with some blessing literature,

\subsubsection{Data Collection Techniques}

The methods used by authors in collecting data are: 
- $\quad$ Literature studies

The author studies and collects theories from various literatures and reading books with problems that are being studied in construction companies.

- Documentation

Namely data collection techniques carried out by recording data sourced from company documents listed on the Indoensia Stock Exchange (IDX).

\subsection{Data Analysis Techniques}

To know the regression model actually shows a significant and representative relationship, then the model must meet the classic assumption test of regression: (1) Normality Test; (2) Multicholinearity Test; (3) Autocorrelation Test; (4) Heteroskedaity Test.

\subsection{Multiple Regression Analysis}

The analysis technique that will be used in this study is a multiple linear regression analysis technique to obtain a comprehensive picture of the relationship between one variable and another. The independent variables used consist of Profitability (ROA), Liquidity (CR) Dividends per Share (DPR).

\section{Result and Discussions}

\subsection{Description of Financial Performance Research Results}

To know the financial performance is indicated by the value of the research measuring instrument that is the ratio of the resulting company. The financial performance observation period used in this study is in the period $2015-2019$.

\section{Return of Assets (ROA)}

Table 3 Calculation of Return Of Assets 2015 - 2019

\begin{tabular}{llllll}
\hline \multirow{2}{*}{\multicolumn{1}{c}{ Name Company }} & \multicolumn{5}{c}{ Return of Assets (\%) } \\
\cline { 2 - 6 } & 2015 & 2016 & 2017 & 2018 & 2019 \\
\hline Ascet Indonusa Tbk & $219 \%$ & $270 \%$ & $290 \%$ & $24 \%$ & $-108 \%$ \\
Adhi Karya (Persero) Tbk & $277 \%$ & $157 \%$ & $182 \%$ & $214 \%$ & $182 \%$ \\
Nusa Konstruksi Enjiniring Tbk & $2 \%$ & $-2488 \%$ & $85 \%$ & $85 \%$ & $-847 \%$ \\
Nusa Raya Cipta Tbk & $994 \%$ & $474 \%$ & $655 \%$ & $523 \%$ & $411 \%$ \\
Pembangunan Perumahan (Persero) & $442 \%$ & $368 \%$ & $413 \%$ & $373 \%$ & $204 \%$ \\
Surya Semesta Internusa Tbk & $593 \%$ & $140 \%$ & $1402 \%$ & $121 \%$ & $168 \%$ \\
Total Bangun Perseda Tbk & $672 \%$ & $750 \%$ & $713 \%$ & $633 \%$ & $592 \%$ \\
Wijaya Karya (Persero) Tbk & $359 \%$ & $386 \%$ & $297 \%$ & $350 \%$ & $422 \%$ \\
Waskita Karya (Persero) Tbk & $346 \%$ & $295 \%$ & $429 \%$ & $371 \%$ & $84 \%$ \\
\hline Average & $434 \%$ & $39 \%$ & $496 \%$ & $299 \%$ & $15 \%$ \\
\hline Sourc: Data Processing Results
\end{tabular}

Source: Data Processing Results (2020)

From the table of return of assets value can be known that the highest financial performance seen from Return of Assets among 9 companies in 2015 is Nusa Raya Cipta Tbk because it has a Return Of Assets value of 994\% which is above the average of construction companies, and the lowest is Nusa Konstruksi Enjiniring Tbk because it has a Return Of Assets $2 \%$ is below the average construction company of $434 \%$.

In 2016, the highest Return Of Assets is owned by PT. Total Bangun Perseda Tbk because it has a Return Of Assets of $750 \%$ which is above the average of construction companies, and the lowest is PT. Nusa Konstruksi Enjiniring Tbk 
because it has a return of assets minus $-2488 \%$ is below the average construction company of $39 \%$.

In 2017, the highest Return Of Assets is still occupied by PT. Surya Semesta Internusa Tbk because it has a Return Of Assets of $1402 \%$ which is above the average of construction companies, and the lowest occurred at PT. Nusa Konstruksi Enjiniring Tbk because it has a Return Of Assets $85 \%$ is below the average construction company of $496 \%$.

In 2018, the highest Return Of Assets was occupied by PT. Total Bangun Perseda Tbk because it has a Return Of assets of $633 \%$ which is above the average of construction companies, and the lowest occurred in PT. Ascet Indonusa Tbk because it has a Return Of Assets of $24 \%$ is below the average construction company of $299 \%$.

In 2019, the return of assets of PT. Total Bangun Perseda Tbk in 2019 was 592\% which is well above the average value, and the lowest occurred at PT. Nusa Konstruksi Enjiniring Tbk because it has a Return Of Assets value of $847 \%$ is below the average construction company of $-15 \%$.

\section{Current Ratio}

Table 4 Current Ratio Calculation Results for 2015 - 2019

\begin{tabular}{llllll}
\hline \multirow{2}{*}{\multicolumn{1}{c}{ Name Company }} & \multicolumn{5}{c}{ Current Ratio (\%) } \\
\cline { 2 - 6 } & 2015 & 2016 & 2017 & 2018 & 2019 \\
\hline Ascet Indonusa Tbk & $153 \%$ & $208 \%$ & $137 \%$ & $119 \%$ & $869 \%$ \\
Adhi Karya (Persero) Tbk & $145 \%$ & $129 \%$ & $141 \% \%$ & $159 \%$ & $149 \%$ \\
Nusa Konstruksi Enjiniring Tbk & $207 \%$ & $120 \%$ & $108 \%$ & $109 \%$ & $117 \%$ \\
Nusa Raya Cipta Tbk & $220 \%$ & $186 \%$ & $195 \%$ & $235 \%$ & $216 \%$ \\
Pembangunan Perumahan (Persero) & $137 \%$ & $155 \%$ & $144 \%$ & $142 \%$ & $137 \%$ \\
Surya Semesta Internusa Tbk & $207 \%$ & $178 \%$ & $193 \%$ & $170 \%$ & $237 \%$ \\
Total Bangun Perseda Tbk & $144 \%$ & $128 \%$ & $126 \%$ & $137 \%$ & $142 \%$ \\
Wijaya Karya (Persero) Tbk & $138 \%$ & $159 \%$ & $134 \%$ & $162 \%$ & $139 \%$ \\
Waskita Karya (Persero) Tbk & $147 \%$ & $127 \%$ & $100 \%$ & $118 \%$ & $109 \%$ \\
\hline Average & $170 \%$ & $154 \%$ & $142 \%$ & $150 \%$ & $235 \%$ \\
\hline Source: Data Processing Results (2020) & & & &
\end{tabular}

From the current ratio table, it can be noted that the highest financial performance seen from the current ratio among 9 companies in 2015 is Nusa Raya Cipta Tbk because it has a current ratio of $220 \%$ which is above the average of construction companies, and the lowest is Residential Development (Persero) because it has a current ratio of 137\% which is below the average construction company of $170 \%$.

In 2016, the highest current ratio was owned by Nusa Raya Cipta Tbk because it has a current ratio of $186 \%$ which is above the average of Construction companies, and the lowest is PT. Nusa Konstruksi Enjiniring Tbk because it has a current ratio of $120 \%$ is below the average construction company of $154 \%$.

In 2017, the highest current ratio is still occupied by PT. Nusa Raya Cipta Tbk because it has a current ratio of 195\% which is above the average of construction companies, and the lowest occurred in PT. Waskita Karya (Persero) Tbk because it has a current ratio of $100 \%$ below the average construction company of $142 \%$.

In 2018, the highest current ratio was occupied by PT. Nusa Raya Cipta Tbk because it has a current ratio of $235 \%$ which is above the average of Construction companies, and the lowest occurred at PT. Nusa Konstruksi Enjiniring Tbk because it has a current ratio of $109 \%$ below the average construction company of $150 \%$.

In 2019, the current ratio of PT. Ascet Indonusa Tbk jumped at $869 \%$ which is well above the average value, and the lowest occurred in Waskita Karya (Persero) Tbk because it has a current ratio of $109 \%$ below the average construction company of $235 \%$. 


\section{Dividend per Share (DPS)}

Table 4 Dividend Per Share Calculation Result for period 2015 - 2019

\begin{tabular}{llllll}
\hline \multirow{2}{*}{\multicolumn{1}{c}{ Name Company }} & \multicolumn{5}{c}{ Dividen Per Share (\%) } \\
\cline { 2 - 6 } & 2015 & 2016 & 2017 & 2018 & 2019 \\
\hline Ascet Indonusa Tbk & $-2,62$ & $-45,4$ & 0,19 & 0,41 & $-0,31$ \\
Adhi Karya (Persero) Tbk & 370 & 25,6 & 391 & 116 & 88,1 \\
Nusa Konstruksi Enjiniring Tbk & 90,0 & 87,1 & 23,3 & 53,9 & 95,6 \\
Nusa Raya Cipta Tbk & 12,5 & 20,5 & 2,86 & 12,5 & 24,4 \\
Pembangunan Perumahan (Persero) & 58,2 & 74,3 & 58,2 & 74,3 & 122 \\
Surya Semesta Internusa Tbk & 2.80 & 15,3 & 18,0 & 11,9 & 19,7 \\
Total Bangun Perseda Tbk & 83,5 & 27,2 & 21,3 & 6,14 & 8,74 \\
Wijaya Karya (Persero) Tbk & 10,4 & 3,99 & 31,7 & 276 & 103 \\
Waskita Karya (Persero) Tbk & 21,3 & 63,1 & 363 & 211 & 182 \\
\hline Average & 71,8 & 30,2 & 101 & 84,8 & 71,7 \\
\hline Soure: Dat Processing Result
\end{tabular}

Source: Data Processing Results (2020)

From the table of dividend value per share it can be known that the highest dividend is seen from the dividend per share figure among 9 companies in 2015 is Nusa Konstruksi Enjiniring Tbk because it has a Dividend Per Share of 90.0x which is above the average of construction companies, and the lowest is PT. Ascet Indonusa Tbk because it has a Dividend Per Share $-2.62 \mathrm{x}$ below the average construction company of $71.8 \mathrm{x}$.

In 2016, the highest Per Share Dividend value is still owned by PT. Nusa Konstruksi Enjiniring Tbk because it has a Dividend Per Share value of 87.1x which is above the average of construction companies, and the lowest is PT. Ascet Indonusa Tbk because it has a Dividend Per Share of $45.4 \mathrm{x}$ below the average construction company of $30.2 \mathrm{x}$

In 2017, the highest Dividend Per Share was occupied by Adhi Karya (Persero) Tbk because it has a Dividend Per Share of $391 \mathrm{x}$ which is above the average of construction companies, and the lowest occurred at PT. Ascet Indonusa Tbk because it has a Dividend Per Share of 0.19x below the average construction company of 101x.

In 2018, the highest Dividend Per Share was occupied by Wijaya Karya (Persero) Tbk because it has a Dividend Per Share of 276x which is above the average of construction companies, and the lowest occurred in PT. Ascet Indonusa Tbk because it has a current ratio of $0.41 \mathrm{x}$ below the average construction company of $84.8 \mathrm{x}$.

In 2019, the value of Waskita Karya Dividend Per Share (Persero) Tbk with a figure of 182x which is well above the average value, and the lowest occurred at Ascet Indonusa Tbk because it has a Dividend value per Share -0.31x below the average construction company of $71.7 \mathrm{x}$.

\subsection{Results}

\subsubsection{Data Normality Test}

The normality test aims to test whether in regression models, variables - bound variables and free variables both have normal or abnormal data distributions. A good regression model is to have a normal distributed residual value. So the normality test is not done on each variable but on its residual value. Normality tests can be performed with histograms, and other tests include researchers using the Kolmogrof Smirnov test and the basis for the decision is as follows:

1) Significance Number (sig) $>0.05$ then data is distributed normally.

2) The significance (sig) of $<0.05$ then the data is not disstrubusi normally. 
Table 5 Normality Test Results

One-Sample Kolmogorov-Smirnov Test

\begin{tabular}{llc}
\hline & & Unstandardized Residual \\
\hline $\mathrm{N}$ & & 45 \\
Normal Parameters & Mean & 0.000 \\
& Std. Deviation & 953.637 \\
Most Extreme Differences & Absolute & 0.092 \\
& Positive & 0.092 \\
& Negative & -0.055 \\
Kolmogorov-Smirnov Z & & 0.617 \\
Asymp. Sig. (2-tailed) & & 0.841 \\
\hline
\end{tabular}

a. Test distribution is Normal.

b. Calculated from data.

Source: Data Processing Results (2020)

From the statistical test results in table 5 that the asymp sig (2-tailed) value in regression is 0.841 . Asymp value. Sig (2-tailed) in regression is greater than at 0.05 . Thus it can be concluded that all residuls in the regression model are distributed normally, thus meeting the assumption of normality $(0.841>0.05)$.

\subsubsection{Multicollinearity Test}

A multicollinearity test was conducted to test whether a regression model found an independent intervariable correlation. To measure multicollinearity can is seen from tolerance value and also Variance Inflication Factor (VIF) value. The basis of the measurement is that if the value of Tolerance $<0.10$ and the value of Variance Inflation Factor $(\mathrm{VIF})>10$ then it is said to occur multicollinearity. The test results can be seen in the table 6.

Table 6 Multicollinearity Test Results

\begin{tabular}{|c|c|c|c|c|c|c|c|c|}
\hline \multicolumn{9}{|c|}{ Coefficients $^{\mathrm{a}}$} \\
\hline \multicolumn{2}{|c|}{ Model } & \multicolumn{2}{|c|}{$\begin{array}{l}\text { Unstandardized } \\
\text { Coefficients }\end{array}$} & \multicolumn{3}{|c|}{$\begin{array}{l}\text { Standardized } \\
\text { Coefficients }\end{array}$} & \multicolumn{2}{|c|}{ Collinearity Statistics } \\
\hline & & B & Std. Error & Beta & $\mathrm{t}$ & Sig. & Tolerance & VIF \\
\hline \multirow[t]{4}{*}{1} & (Constant) & 1975.423 & 362.781 & & 5.445 & $<0.001$ & & \\
\hline & ROA & 234.812 & 106.776 & 1.284 & 2.199 & 0.034 & 0.060 & 1.556 \\
\hline & $\mathrm{CR}$ & 348.644 & 173.263 & 0.377 & 2.512 & 0.014 & 0.085 & 1.709 \\
\hline & DPS & 3.592 & 1.445 & 1.406 & 2.487 & 0.017 & 0.064 & 1.529 \\
\hline
\end{tabular}

a. Dependent Variable: Share Price

Source: Data Processing Results (2020)

Based on the data management results in table 4.6 above can be drawn the conclusion that the value of Tolerance > 0.10 and the value of Variance Inflation Factor (VIF) $<10$ in each variable (ROA, CR, and DPS), so it can be concluded that in all variables there are no symptoms of multicollinearity. 


\subsubsection{Autocorrelation test}

Researchers used an auto correlation test to find out if linear regression equations had a relationship between a tperiod bullying error and a bully error in the t- (previous) period. Regression analysis aims to see how free variables affect bonded variables, so there should be no relationship between each other, in this study, researchers used the Durbin Watson (DW test) test. Durbin Watson's test results can be found in the table 7.

Table 7 Autocorelation Result

\begin{tabular}{ccccc}
\hline D & dL & dU & 4-dL & 4-dU \\
\hline 1,860 & $\mathbf{1 , 3 8 3 2}$ & $\mathbf{1 , 6 6 6 1}$ & $\mathbf{2 , 6 1 6 8}$ & $\mathbf{2 , 3 3 3 8}$ \\
\hline \multicolumn{5}{l}{ Source: Data Processing Results (2020) }
\end{tabular}

Durbin Watson's auto correlation test results in table 6 show the number 1,860 numbers when compared to the DW table values using the degree of trust $\alpha=5 \%$, the number of free variables $(\mathrm{k})=4$, and the amount of data $45(\mathrm{n})$, the Value of the DW table $\mathrm{dL}=1.3832$ and $\mathrm{dU}=1.6661$.

Based on the DW table, the results of the DW figures are located between dU and (4-dU), $1.6661>1.860>2.3338$. So it is concluded that the regression equation of this study has no auto correlation.

\subsubsection{Heteroskedasticity Test}

The heteroskedasticity test has the goal of seeing if in the regression model there is a variant inequality from one residual observation to another. It can be seen that if the dots do not have a specific pattern and do not spread above and below zero on the y-axis, then there is no heteroskedasticity. The test of heteroskedasticity can be seen in the fig. 1 .

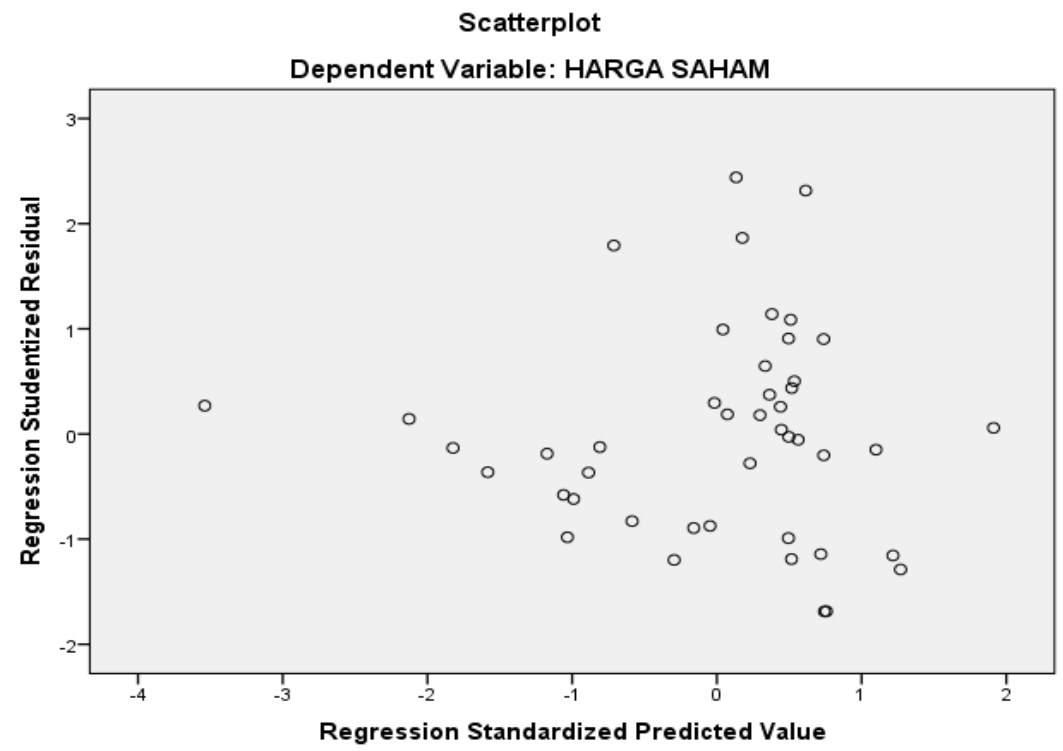

Fig. 1 Heteroskedastisity Test Results Source: Data Processing Results (2020)

From the scatterplot chart above it appears that the spread of data points is diffuse, not gathered just above or below the number 0 on the $\mathrm{Y}$ axis and does not form a specific pattern. So it can be concluded that the linear regression model is double free from the classic assumptions of heteroskedastisity and deserves to be used in research. 


\subsubsection{Multiple Linear Regression Analysis}

This analysis has the goal of looking at the influence between free variables and bound variables that indicate a oneway relationship. The results of the linear regression analysis in this study can be seen in the table 8 .

Table 8 Multiple Linear Regression Analysis Test Results

\section{Coefficients $^{\mathrm{a}}$}

\begin{tabular}{llccccccc}
\hline & & \multicolumn{3}{c}{ Unstandardized Coefficients } & $\begin{array}{c}\text { Standardized } \\
\text { Coefficients }\end{array}$ & $\mathrm{t}$ & Sig. & \multicolumn{2}{c}{ Collinearity Statistics } \\
& \multicolumn{1}{c}{ Model } & B & Std. Error & Beta & & & Tolerance & VIF \\
\hline 1 & (Constant) & 1975.423 & 362.781 & & 5.445 & $<0.001$ & & \\
& ROA & 234.812 & 106.776 & 1.284 & 2.199 & 0.034 & 0.060 & 1.556 \\
CR & 348.644 & 173.263 & 0.377 & 2.512 & 0.014 & 0.085 & 1.709 \\
DPS & 3.592 & 1.445 & 1.406 & 2.487 & 0.017 & 0.064 & 1.529 \\
\hline
\end{tabular}

a. Dependent Variable: Share Price

Source: Data Source:Processing Results (2020)

Based on the above processing results, the linear regression analysis model between variable $\mathrm{X}$ and variable $\mathrm{Y}$ can be transformed into the following equation model:

$$
\mathrm{Y}=1975.423+234.812 \mathrm{X}_{1}-348.644 \mathrm{X}_{2}+3.592 \mathrm{X}_{3}+\mathrm{e}
$$

From the result of these multiple linear regression equations, each independent variable can be interpreted as impacting the share price as follows:

1) Constants amounting to 1975.423 means that if the value of other variable regression coefficients is zero (0) then the Share Price coefficient (Y) is positive value of 1975.423.

2) Return of Assets (X1) regression coefficient is positively marked and the amount is 234.812 meaning that if the Current Ratio increases by 1 unit, then the Share Price coefficient (Y) will increase by 234.812 .

3) Current Ratio (X2) is positively marked and the amount is 348.644 meaning the Current Ratio has increased by 1 unit, then the share price coefficient $(\mathrm{Y})$ will decrease by 348.644.

4) Dividend Per Share (X3) is positively marked and the amount is 3,592 meaning Dividend Per Share has increased by 1 unit, then the share price coefficient (Y) will increase by 3.592 .

\subsubsection{The T Test}

Partial regression testing is intended to see if one independent variable proxy individually has an influence on dependent variables assuming other independent variables are constant. The test was conducted 2-way testing with $\alpha$ $=5 \%$ and $\mathrm{df}=\mathrm{n}-\mathrm{k}-1$. Where $\alpha=$ real level, $\mathrm{n}=$ amount of data, $\mathrm{k}=$ many independent variables. The testing criteria are as follows:

a) If $\mathrm{t}$ count $<\mathrm{t}$ table, then the independent variable individually has no effect on the dependent variable.

b) If $t$ count $>t$ table, then the independent variable individually affects the dependent variable.

c) If the probability (significance) is greater than $\alpha=0.05$ then independent variables individually have no effect on dependent vriabel. Conversely, if it is smaller than 0.05 then independent variables individually affect dependent variables.

Here are the $t$ test results from this study in table 9. 
Table 9 Result of T test

\section{Coefficients $^{\mathrm{a}}$}

\begin{tabular}{|c|c|c|c|c|c|c|c|c|}
\hline & \multirow{2}{*}{ Model } & \multicolumn{2}{|c|}{ Unstandardized Coefficients } & \multirow{2}{*}{$\begin{array}{c}\text { Standardized } \\
\text { Coefficients } \\
\text { Beta }\end{array}$} & \multirow{2}{*}{$\mathrm{t}$} & \multirow{2}{*}{ Sig. } & \multicolumn{2}{|c|}{ Collinearity Statistics } \\
\hline & & $\mathrm{B}$ & Std. Error & & & & Tolerance & VIF \\
\hline \multirow[t]{4}{*}{1} & (Constant) & 1975,423 & 362,781 & & 5,445 & 000 & & \\
\hline & ROA & 234,812 & 106,776 & 1,284 & 2,199 & 034 &, 060 & 1,556 \\
\hline & $\mathrm{CR}$ & 348,644 & 173,263 & ,377 & 2,512 & ,014 & ,085 & 1,709 \\
\hline & DPS & 3,592 & 1,445 & 1,406 & 2,487 & 017 & 064 & 1,529 \\
\hline
\end{tabular}

Source:Processing Results (2020)

Based on the results of the T test in table 4.10 above with two-way/two-sided research where looking for $\mathrm{t}_{\text {table }}(\mathrm{a}=5 \%$ with two-way/two-sided research; $d f=n-k-1=45-3-1=41$ then obtained a value of 2.019 as $\mathrm{t}_{\text {table }}$ so obtained the following results:

\section{1) Return Of Assets (X1) to share price (Y)}

From the table 9 , sig value of 0.034 . The sig value is smaller than the probability value of 0.034 which is $0.034>0.05$ then $\mathrm{H} 1$ is accepted and $\mathrm{H} 0$ rejected Variable $\mathrm{X} 1$ has $\mathrm{t}_{\text {count }} 2.199$ with $\mathrm{t}$ table 2.019. So $\mathrm{t}_{\text {count }} 2.199>\mathrm{t}_{\text {table }} 1.661$ can be concluded that variable $\mathrm{X} 1$ has a contribution to $\mathrm{Y}$. Positive $\mathrm{t}$ value indicates that $\mathrm{X} 1$ has a direct relationship with $\mathrm{Y}$. So it can be concluded return of assets has a significant influence on the Share Price.

\section{2) Current Ratio (X2) to share price (Y)}

From the table 9, sig value of 0.014 . The sig value is smaller than the probability value of 0.014 which is $0.014>0.05$ then $\mathrm{H} 1$ is accepted and $\mathrm{H} 0$ is rejected Variable $\mathrm{X} 1$ has $\mathrm{t}_{\text {count }} 2,512$ with $\mathrm{t}_{\text {table }} 2,019$. So $\mathrm{t}_{\text {count }} 2,512>\mathrm{t}_{\text {table }} 2,019$ can be concluded that variable $\mathrm{X} 1$ has a contribution to $\mathrm{Y}$. Positive $\mathrm{t}$ value indicates that $\mathrm{X} 1$ has a direct relationship with $\mathrm{Y}$. So it can be concluded return of assets has a significant influence on the Share Price.

\section{3) Dividend Per Share (X3) to share price (Y)}

From the table 9 , sig value of 0.017 . The sig value is smaller than the probability value of 0.017 which is $0.017>0.05$ then $\mathrm{H} 1$ is accepted and $\mathrm{H} 0$ is rejected Variable $\mathrm{X} 1$ has $\mathrm{t}_{\text {count }} 2,487$ with $\mathrm{t}_{\text {table }} 2,019$. So tcount 2,487 $>\mathrm{t}_{\text {table }} 2,019$ can be concluded that variable $\mathrm{X} 1$ has a contribution to $\mathrm{Y}$. Positive $\mathrm{t}$ value indicates that $\mathrm{X} 1$ has a direct relationship with Y. So it can be concluded dividends per share have a significant influence on the Share Price.

\subsubsection{The F Test}

Simultaneous regression testing (overall) shows whether independent variables together have an influence on dependent variables with $\alpha=5 \%, \mathrm{dfn}=\mathrm{k}$ and $\mathrm{dfd}=\mathrm{n}-\mathrm{k}-1$; where $\alpha=$ real level, $\mathrm{n}=$ number of data, $\mathrm{k}=$ number of independent variables. The testing criteria are as follows:

- If $\mathrm{F}$ calculates the $<\mathrm{F}$ table, then the independent variables together have no effect on the dependent variable. If $\mathrm{F}$ counts $>\mathrm{F}$ of the table, then the independent variables together affect the dependent variables.

- If the probability (significance) is greater than $\alpha=0.05$ then the independent variables together have no effect on the dependent vriabel. Conversely, if it is smaller than 0.05 then the independent variables together affect dependent variables.

Here are the $\mathrm{F}$ test results from this study: 
Table 10 Results of $\mathrm{F}$ test

\begin{tabular}{|ll|r|r|r|r|r|}
\hline \multicolumn{1}{|c|}{ ANOVA $^{\text {b }}$} \\
\hline 1 & Sum of Squares & df & Mean Square & F & Sig. \\
\hline & Regression & 7385982.410 & 3 & 2461994.137 & 2.523 & $0.071^{\mathrm{a}}$ \\
& Residual & 40014698.034 & 41 & 975968.245 & & \\
& Total & 47400680.444 & 44 & & & \\
\hline
\end{tabular}

a. Predictors: (Constant), DPS, CR, ROA

b. Dependent Variable: HARGA SAHAM

Source:Processing Results (2020)

Based on the results of the ANOVA or F Test test in table 10 with $\alpha=5 \%, \mathrm{df}_{\mathrm{n}}=\mathrm{k}=4$ and $\mathrm{df}_{\mathrm{d}}=\mathrm{n}-\mathrm{k}-1=45-3-1=41$ so that it obtained $f$ calculated results of 2,523 with a probability level of 0.005 (significant), while $F_{\text {table }}$ was 2.60 with a significance level of 0.05.05. It can be concluded that ROA, CR and DPS have a simultaneous influence (together) on stock price variables. Because $\mathrm{F}_{\text {count }}>\mathrm{F}_{\text {table }}$ is $2,523>2.60$. And significant research $<0.05$ that is $0.000<0.05$. This means that these variables can be used as a means of predicting the share price in this research model is acceptable.

\subsubsection{Determination Coefficient Test (R2)}

The determination coefficient ( $\mathrm{R}$ Square) essentially measures how far the model is able to explain variations in dependent variables. The value of $\mathrm{R}$ Square is between zero and one. If the $\mathrm{R}$ Square value gets closer to one, the independent variables provide all the information needed to predict the variation of dependent variables. The smaller $\mathrm{R}$ Square, the smaller the ability of independent variables to explain the variation in dependent variables.

Table 11 Determination Coefficient Test Results (R2)

\begin{tabular}{cccccc}
\multicolumn{6}{c}{ Model Summary $^{\mathbf{b}}$} \\
\hline Model & $\mathrm{R}$ & R Square & Adjusted R Square & $\begin{array}{c}\text { Std. Error of the } \\
\text { Estimate }\end{array}$ & Durbin-Watson \\
\hline 1 & $0.552^{\mathrm{a}}$ & 0.476 & 0.394 & 0.91105 & 1.860 \\
\hline
\end{tabular}

a. Predictors: (Constant), DPS, CR, ROA

b. Dependent Variable: Share Price

Source:Processing Results (2020)

Based on the data processing results in table $4.12 \mathrm{R} 2$ value can be seen from the Adjusted R Square column which is 0.476 or equal to $47.5 \%$. The value means that the independent variables used in this study are ROA, CR, DPS affecting dependent variables namely the Share Price of $47.5 \%$, while the remaining $52.5 \%$ is influenced by other factors not described in this study.

\subsection{Discussion}

\section{Effect of Return of Assets on Share Price}

ROA has a probability value of 0.034 smaller than 0.05 , so it is known that ROA has a positive effect on the Share Price. With a coefficient of 2,199 means that if the ROA value increases by $1 \%$ then the ROA will increase by $2.199 \%$ while other variables are constant. Thus the results of the study showed that ROA had a positive and significant effect on the share price. The higher the Return Of Assets (ROA) means the greater the company's ability to pay its debts.

The high Return of Assets (ROA) indicates the profitability of a company is high, and this is advantageous for investors because the company will be able to deal with business fluctuations. 


\section{Effect of Current Ratio on Share Price}

CR has a probability value of 0.014 smaller than 0.05 , so it is known that CR has a positive effect on the Share Price. With a coefficient of 2,512 means that if the CR value increases by $1 \%$ then the CR will increase by $2,512 \%$ while other variables are constant. Thus the results of the study showed that CR had a positive and significant impact on the share price. The higher the Current Assets (CR) means the greater the company's ability to pay its debts.

High Current Assets (CR) indicates the liquidity of a company is high, and this is advantageous for investors because the company will be able to deal with business fluctuations.

\section{Effect of Dividends Per Share on Share Price}

DPS has a probability value of 0.017 smaller than 0.05 , so it is known that DPS has a positive effect on the Share Price. With a coefficient of 2,487 means that if the dps value increases by $1 \%$ then DPS will increase by $2,487 \%$ while other variables are constant. Thus the results showed that DPS had a positive and significant impact on the share price. The higher the Dividend Per Share (DPS) means the greater the company's ability to pay its debts.

A high Dividend Per Share (DPS) indicates the company's share per share is high, and this is beneficial for investors as the company will be able to deal with business fluctuations.

\section{Effect of Return Of Assets, Current Ratio, and Dividends Per Share on Share Price}

The results showed that Return Of Assets (X1), Current Ratio (X2), Dividend Per Share (X3), and significant positive effect on the Share Price (Y). From the results of multiple linear analysis obtained Fcount $(2,523)$ greater than Ftable with a level of significance of $5 \%$ and significance $(0.071)<\alpha(0.05)$, so it can be concluded that the fifth hypothesis stating Return On Assets (X1), Current Ratio (X2), Dividend Per Share (X3), and significant positive effect on the Share Price (Y). conversely, if the value of Return Of Assets (X1), Current Ratio (X2), Dividend Per Share (X3), and lower is expected to be a decrease in the value of the Share Price (Y). The increase in the Share Price value of construction companies listed on the Indonesia Stock Exchange is not only influenced by the large number of investors, for that can be done by evaluating each profit value that can affect the level of progress in the value of the shares, evaluating net income and earnings each period, and evaluating each increase in the value of the share price by increasing the profit in the company, thus, changes in the value of the share price, can be directed to increase positively in the following years.

\section{Conclusions}

The partial results show that Retrun On Assets (X1) has a significant positive effect on the Share Price (Y), this can be seen from the value of $\mathrm{T}_{\text {count }}(2,199)>\mathrm{T}_{\text {table }}(2,199)$ and sig $(0.034)>\alpha(0.05)$. This means that the high Return On Assets will be followed by an increase in the share price of construction companies.

The results of the study partially showed that the Current Ratio (X2) had a significant positive effect on the Share Price $(Y)$, this can be seen from the value of $T_{\text {count }}(2,512)>T_{\text {table }}(2,199)$ and sig $(0.801)>\alpha(0.05)$. This means that the high Current Ratio will be followed by an increase in the share price of construction companies.

The results of the study partially show that Dividends Per Share (X3) have a significant positive effect on the Share Price $(Y)$, this can be seen from the value of $T_{\text {count }}(2,524)>T_{\text {table }}(2,199)$ and sig $(0.017)<\alpha(0.05)$. This means that the high Dividend Per Share will be followed by an increase in the share price of construction companies.

For investors the results of this research are expected to provide input to investors in investing their shares in the Indonesia Stock Exchange (IDX) or in the capital market. Changes to microeconomic factors (Current Ratio, Debt to Equity Ratio, and Return On Investement) can be used as investors in the decision to invest.

For this Research Company proves that Return Of Assets, Current Ratio, Dividend Per Share equally has a significant influence on the share price, so it is expected that the Construction sector maintains the company's performance. The Company should also pay attention to the proportion of the profitability of the company and the value of Liquidity because it can affect investor confidence in investing in the stock exchange, especially in the Construction sector, then 
it is expected that the company can maintain its Profit, Liquidity, and Dividend value so that the company's growth runs well. Because if the company pays attention and maintains these three factors investors will be more interested in investing their shares in the company.

For further research, it is best to add a company that is researched that is not only the criteria that exist in the sample but all companies engaged in the same field, then also add years of research that is not only in 2015 - 2019, and can add variables.

\section{References}

Ahmed, F., Advani, N., \& Kanwal, S. (2018). Earnings management and dividend policy: Empirical evidence from major sectors of Pakistan. International Journal of Economics and Financial Issues, 8(3), 182.

Alexander, H.B. (2017, February 10). Sektor Konstruksi Penyumbang Ketiga Pertumbuhan Ekonomi Nasional. Retrieved:

https://properti.kompas.com/read/2017/02/10/220000321/sektor.konstruksi.penyumbang.ketiga.pertumbuhan.e konomi.nasional?page=all

Arikunto, S. (2010). Metode Peneltian. Jakarta: Rineka Cipta.

Brigham, E. F., \& Houston, J. F. (2015). Fundamentals of financial management. Nelson Education.

Fauzi, I. D., \& Rukmini, R. (2018). The Effect of Financial Performance Measured With Rentability Ratio Against Dividend Payout Ratio (Empirical Study on Manufacturing Companies Group Listed on BEI). International Journal of Economics, Business and Accounting Research (IJEBAR), 2(01).

Hartono, J. 2013. Portfolio Theory and Investment Analysis (Teori Portofolio dan Analisis Investasi). Yogyakarta: BPFE-Yogyakarta

Kasmir. (2014). Basic Banking (Dasar-dasar Perbankan). Jakarta: Rajagrafindo Persada.

Reeve, J. M. 2010. Introduction of Accounting (Pengantar Akuntansi). Jakarta: Salemba Empat.

Rusnindita, K. R. (2020). Analysis Of Size, ROA, And Growth Of Corporate Value; With Variable Capital Structure As Intervening. International Journal of Science, Engineering and Information Technology, 4(2), 203-208.

Schwaiger, R., Kirchler, M., Lindner, F., \& Weitzel, U. (2020). Determinants of investor expectations and satisfaction. A study with financial professionals. Journal of Economic Dynamics and Control, 110, 103675.

Syamsuddin, L. 2009. Manajemen Keuangan Perusahaan: Konsep Aplikasi dalam Perencanaan, Pengawasan, dan Pengambilan Keputusan. Jakarta: Rajawali Pers.

Tandelilin, E. 2010. Portfolio and Investment Theory and Applications (Portofolio dan Investasi: Teori dan Aplikasi). Yogyakarta: Kanisius

Weston, J. F., \& Copeland, T. E. (1997). Financial Management (Manajemen Keuangan). Jakarta: Binarupa Aksara.

Willy, S. (2017). Analysis of financial ratios to measure the company's performance in the sectors of consumer goods at PT. Nippon Indosari Corpindo, Tbk and PT. Mayora Indah, Tbk. International Journal of Business and Economic Affairs, 2(1), 45-51. 